\title{
IDENTITAS BUDAYA PADA MAHASISWA BATAK TOBA YANG KULIAH DI MEDAN
}

\author{
Meutia Nauly, \\ Vivi Fransisca \\ Departemen Psikologi Sosial \\ Fakultas Psikologi, Universitas Sumatera Utara \\ J1. Dr. Mansyur No.7, Kampus USU, Padangbulan, Medan \\ Sumatera Utara, Indonesia \\ 'e-mail:tinauly@gmail.com
}

\begin{abstract}
The phenomenon that underlies the condition of Batak students who grew up in the city of Medan, which no longer uses the language batak, even with their own families, and a lack of understanding for the value of the main culture Bataknese, namely Hamoraon, Hagabeon and Hasangapon and understanding Dalihan na tolu as a concept family relationship in the Batak, raised a main concern of this study. This was a non-experimental and comparison study that aimed to find differences of cultural identity, which consists various aspects, including: perception, importance, esteem, maintenance and behavioral expression, on Batak Toba students who enrolled at the University of North Sumatra, in terms of where the subjects were raised. Results of the data analysis showed the existence of significant difference of the cultural identity in student's Batak Toba, who enrolled at the University of North Sumatra, in terms of where the subject was raised-between the ones who were born and raised in Batak Toba and within the city of Medan. The results shows that cultural identity of students who were born and raised in Batak Toba tends to be stronger than the one possessed by students who were born and raised from the city of Medan. It expressed the need to keep transmitting these values to the younger generation, so that these values remain intact.
\end{abstract}

Keywords: cultural identity; Batak Toba culture

\begin{abstract}
Abstrak-Penelitian ini diawali dengan semakin banyaknya ditemukan mahasiswa Batak yang dibesarkan di Kota Medan, yang tidak lagi menggunakan bahasa Batak, bahkan dengan keluarga mereka sendiri, dan kurangnya pemahaman akan nilai budaya utama Orang Batak, yakni Hamoraon, Hagabeon dan Hasangapon serta pemahaman akan Dalihan na Tolu sebagai konsep hubungan kekeluargaan pada orang Batak. Penelitian ini merupakan penelitian komparasi non eksperimental yang bertujuan untuk mengetahui perbedaan identitas budaya yang terdiri dari aspek perception, importance, esteem, maintenance dan behavioral expression pada mahasiswa Batak Toba yang berkuliah di Universitas Sumatera Utara, ditinjau dari tempat subjek dibesarkan. Hasil analisis data menunjukkan adanya perbedaan identitas budaya pada mahasiswa Batak Toba yang berkuliah di Universitas Sumatera Utara, ditinjau dari tempat subjek dibesarkan, dalam hal ini antara yang lahir dan besar di Tanah Batak Toba dan yang lahir dan besar di Kota Medan. Identitas budaya
\end{abstract}


mahasiswa yang lahir dan besar di Tanah Batak Toba lebih kuat dibandingkan yang dimiliki oleh mahasiswa yang lahir dan besar di Kota Medan. Diutarakan adanya kebutuhan untuk tetap mentransmisikan nilai-nilai budaya terhadap generasi muda, agar nilai-nilai ini tetap terjaga.

Kata kunci: identitas budaya; budaya Batak Toba

\section{PENDAHULUAN}

Penduduk Kota Medan memiliki ciri penting yang meliputi keberagaman unsur agama, suku etnis, budaya dan adat istiadat sehingga memunculkan karakter sebagian besar penduduknya bersifat terbuka. Meningkatnya laju pertumbuhan penduduk serta arus perpindahan antar daerah (migrasi) dan proses urbanisasi merupakan hal yang mempengaruhi kependudukan di dalam Kota Medan (RPJM Pemerintah Kota Medan, dalam Pemerintah Kota Medan, 2012). Arus perpindahan penduduk yang bersifat internal di Sumatera Utara ini membuat daerah perkotaan dijadikan sasaran dalam aktivitas perpindahan penduduk antar kabupaten atau antar kota, terutama Kota Medan. Oleh karena itu, wajar jika hasil sensus penduduk Kota Medan memperoleh angka tertinggi masuknya arus migrasi dari 13 kabupaten yang ada di Sumatera Utara. (BKKBN Provinsi Sumatera Utara, dalam Surianingsih, 2006).

Di Provinsi Sumatera Utara, faktor pendorong berpindahnya penduduk ke kota adalah karena daerah tempat asal tidak memungkinkan untuk memenuhi kebutuhan, serta keadaan lingkungan dari daerah tujuan yang dilihat lebih menjanjikan, misalnya pendidikan yang lebih baik (Surianingsih, 2006). Salah satu alasan yang menyebabkan jumlah penduduk di Kota Medan paling banyak adalah terus bertambahnya penduduk area pedesaan yang ingin melanjutkan pendidikan ke tingkat yang lebih tinggi, misalnya mahasiswa baru ("Inilah Penyebab Penduduk Medan Membludak," 2011). Banyak pemuda dari daerah-daerah luar Kota Medan yang lebih memilih bermigrasi ke Kota Medan, dengan tujuan untuk menambah ilmu atau menuntut ilmu di perguruan tinggi yang tidak tersedia di desa asalnya (Surianingsih, 2006). Pada tahun 2011, beberapa perguruan tinggi negeri di Kota Medan, termasuk Universitas Sumatera Utara, menerima mahasiswa baru mencapai lebih dari sembilan ribu jiwa, yang sebagiannya adalah penduduk urban (“Inilah Penyebab Penduduk Medan Membludak,”2011).

Suku bangsa Batak Toba, termasuk salah satu suku bangsa dengan jumlah penduduk yang banyak di Medan, di antara beberapa suku bangsa lainnya seperti Jawa, Minang dan Tionghoa (Pelly, 1994). Lebih lanjut, Pelly (1994) mengemukakan bahwa Batak Toba juga dikenal sebagai salah satu suku bangsa perantau. Pola perantauan mereka disebut juga sebagai perantauan yang "ekspansionis", dengan motto "mendapatkan anak dan tanah" (halalui anak halalui tano). "Anak dan tanah" bagi mereka adalah simbol martabat, kekuasaan dan kekayaan, sebagaimana dengan misi budaya mereka. Tentunya relatif berbeda cara membesarkan anak-anak dari keluarga Batak yang bermukim di kampung dengan 
yang bermukim di Kota Medan. Di Kota Medan, keluarga Batak akan dipengaruhi oleh budaya Medan sebagai sebuah kota yang multikultural. Keunikan dari Kota Medan adalah tidak adanya budaya yang dominan namun masih ditandai dengan cukup kuatnya ikatan kekerabatan di antara suku-suku yang ada. Pada orang Batak Toba, contohnya, meskipun hidup di Medan, mereka tetap memiliki Punguan, yakni semacam kelompok kekerabatan berdasarkan marga, yang berperan untuk menjalankan adat maupun semacam serikat tolong-menolong di antara mereka (Baiduri, 2015). Meskipun demikian tampaknya intensitas untuk menjalankan adat sepenuhnya menjadi tantangan tersendiri bagi orang Batak, terutama di generasi kedua, yakni generasi yang dilahirkan dan dibesarkan di Medan.

Dari hasil komunikasi personal yang dilakukan terhadap beberapa mahasiswa Batak Toba yang dibesarkan di Kota Medan dan yang dibesarkan di Tanah Batak Toba, ada perbedaan yang tampak di antara keduanya. Berikut ini adalah hasil komunikasi personal terhadap dua mahasiswa Batak Toba yang dibesarkan di Kota Medan saat ditanyai tentang hal-hal yang berkenaan dengan Batak Toba dalam kehidupan sehari-hari mereka:

"kalo di rumah kami itu, jarang kali lah pake-pake bahasa Batak. Paling pun kalo pake, paling cuma bilang olo-olo, atau kalimat-kalimat singkat gitu kayak 'dang boi'. Kalo ke pesta, ya cuma orangtua la yang pergi, aku gak mau, malas kali kadang. Trus, kalo gereja gitu, aku udah jarang kali gereja di HKBP [salah satu gereja adat], pokoknya lebih enak yang fleksibel aja lah."

(NN, komunikasi personal,13 Januari 2012)

"kalo bahasa batak, mamak bapakku gak sering sih. Palingan kalo ada hal penting, supaya orang lain gak tau apa yang dibicarakan aja. Aku sendiri taunya sedikit-sedikit-lah, kalo orang ngomong ya ngertilah. Kalo di batak ini yang malas kadang, di keluarga itu sepertinya anak laki-laki itu adalah segalanya. Gitu-gitulah.”

(NN, komunikasi personal, 15 Januari 2012)

Berdasarkan komentar di atas dapat dilihat ada unsur Batak Toba yang sudah mulai memudar, misalnya penggunaan bahasa Batak Toba. Jameson (2007) menyebutkan bahwa bahasa membatasi kelompok budaya, yang merupakan sistem simbolik yang paling sering digunakan untuk menyampaikan budaya. Dalam penelitian Berry dkk (1997) mengenai identitas budaya Suku Aborigin, diungkapkan bahwa pengetahuan tentang bahasa asli dari suatu suku merupakan hal pokok dalam membentuk identitas budaya seseorang. Para partisipan dalam penelitian Berry dkk (1997), mereka yang menguasai bahasa asli sukunya merasa sangat senang dan bangga. Sebaliknya, partisipan yang tidak menguasainya menekankan bahwa mempelajari kembali bahasa asli suku mereka merupakan prioritas utama bagi mereka dan keturunan mereka kelak.

Tempat tinggal yang terletak jauh dari lokasi budaya asal dapat menyebabkan seseorang kehilangan kontak dengan budaya mereka. Sementara, seseorang yang tetap berhubungan dengan 
budayanya, cenderung memiliki kepekaan terhadap identitas budaya yang kuat pula (Berry, 1999). Di dalam penelitian ini, kami berasumsi bahwa orang Batak Toba yang dibesarkan di Kota Medan akan memiliki identitas budaya yang berbeda dengan orang Batak Toba yang dibesarkan di Tanah Batak Toba.

Penelitian tentang orang Batak Toba ini pernah dilakukan sebelumnya oleh Nainggolan (2006), yang dilakukan terhadap orang Batak Toba yang tinggal di Jakarta. Hasilnya menunjukkan bahwa orang Batak Toba di Jakarta nyatanya merasa lebih orang Indonesia, artinya identitas mereka sebagai orang Indonesia lebih utama dibandingkan identitas mereka sebagai orang Batak. Hal ini jika dibandingkan dengan mereka yang tinggal di kampung halaman, khususnya pada generasi kedua. Dalam penelitian ini, kami mencoba untuk membandingkan identitas budaya pada orang Batak Toba antara yang dibesarkan di Kota Medan dan yang dibesarkan di Tanah Batak Toba. Berdasarkan penelitian sebelumnya, serta penjelasan teoritis mengenai identitas budaya, kami berasumsi bahwa ada perbedaan identitas budaya orang Batak Toba yang dibesarkan di Kota Medan dengan yang dibesarkan di Tanah Batak Toba; yaitu bahwa orang Batak Toba yang dibesarkan di Tanah Batak Toba diasumsikan memiliki identitas budaya yang lebih kuat dibandingkan orang Batak Toba yang dibesarkan di Kota Medan.

\section{Identitas Budaya}

Istilah identitas memiliki keterkaitan yang dekat dengan konsep diri, yang terdiri dari dua komponen. Komponen pertama (yaitu diri atau self) memiliki dua kemungkinan arti; yang pertama adalah diri sebagai subjek, dan yang kedua adalah diri sebagai objek (Taylor \& Dube, dalam Berry 1999). Komponen lain (yaitu concept), mengarah pada pengetahuan atau keyakinan seseorang. Ketika digabungkan, istilah konsep diri berarti pengetahuan atau keyakinan yang dimiliki individu tentang dirinya sendiri (Wylie, dalam Berry, 1999). Berbeda dengan konsep diri, identitas biasanya mengandung suatu rasa kelekatan (attachment) yang dimiliki individu terhadap identitas itu sendiri (Aboud; Hocoy; Keefe, dalam Berry 1999). Sebagaimana yang diungkapkan Tajfel (1982), identitas budaya bukan hanya sekedar konsep diri yang meliputi pengetahuan seseorang tentang keanggotaannya dalam suatu kelompok atau kelompok sosial, namun juga berkaitan dengan nilai dan perasaan emosional yang melekat pada keanggotaan tersebut. Pengetahuan tersebut dibedakan menjadi dua, yaitu pengetahuan yang dimiliki seseorang tentang dirinya sebagai individu (misalnya, kemampuan, sikap dan kepribadian seseorang), dan pengetahuan yang dimiliki seseorang tentang dirinya sebagai anggota dari suatu kelompok (misalnya, kelompok sosial, kelas, etnis dan kebangsaan) (Berry, 1999).

Pengetahuan yang dimiliki seseorang tentang dirinya sebagai individu dapat dilihat dari pernyataan seperti ini, "Saya seorang yang jujur, saya seorang yang aktif", atau disebut sebagai identitas personal. Pengetahuan yang dimiliki seseorang tentang dirinya sebagai anggota dari suatu kelompok dapat dilihat dari pernyataan seperti ini, "Saya orang Kanada", atau disebut sebagai identitas sosial seseorang (Wong-Rieger \& Taylor, dalam Berry, 1999). 
Identitas sosial bisa bersumber dari berbagai kelompok, misalnya kelas sosial, partai politik atau asosiasi lainnya. Selain dari kelompok-kelompok tersebut di atas, ada kelompok yang lebih penting dan lebih besar, yang dapat memberikan identitas sosial bagi anggotanya, yakni kelompok budaya (Phinney, 1990; UNESCO, dalam Berry, 1999). Identitas sosial dari kelompok budaya inilah yang disebut sebagai identitas budaya (Batia \& Ram, dalam Schwartz, Montgomery, \& Ervin, 2006).

Dibandingkan dengan identitas sosial, identitas budaya ini berkaitan dengan rasa solidaritas terhadap hal-hal idealis dari kelompok budaya yang bersangkutan, dan hasilnya ialah berupa sikap, keyakinan, dan perilaku seseorang terhadap dirinya dan orang lain (Jensen; Roberts, dkk.; dalam Schwartz, Montgomery, \& Ervin, 2006). Identitas budaya ini dapat bersifat formal dan informal dalam kelompok yang memberi dan menanamkan pengetahuan, keyakinan, nilai, sikap, tradisi, dan cara hidup (Kim, 2006). Identitas budaya mengarah pada serangkaian aspek kompleks yang secara bersamaan mengindikasikan bagaimana seseorang berpikir tentang dirinya dalam hubungannya dengan kelompok budayanya (Berry, 1999).

Berikut ini adalah klasifikasi identitas:

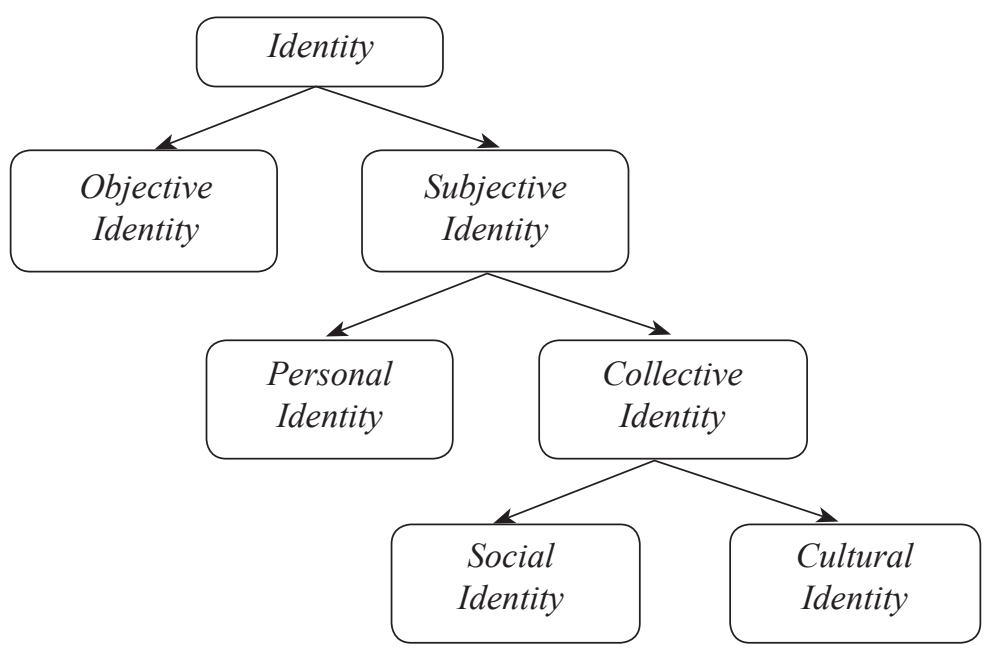

Gambar 1. Klasifikasi Identitas Sumber: Jameson (2007)

Dari gambar di atas, dapat diungkapkan bahwa identitas budaya merupakan satu bagian dari suatu konsep yang luas dalam identitas diri. Identitas objektif merupakan identitas yang ditunjukkan dalam akte kelahiran seseorang, passport, laporan kredit, dan berkas penting lainnya, yang jelas berbeda dengan identitas subjektif, yaitu perasaan seseorang tentang siapa dirinya sebagai manusia (Jameson, 2007).

Berry(1999), mengungkapkan bahwa identitas budaya memiliki lima aspek yang dapat mengungkapkan bentuk-bentuk identtias budaya yang dimiliki seseorang. Pertama ialah persepsi (perception), mencakup aspek pengetahuan: persepsi atau keyakinan seseorang bahwa ia adalah anggota suatu kelompok budaya. Aspek ini mengindikasikan bagaimana seseorang memandang identitas dirinya, 
apakah sebagai bagian dari kelompok budayanya, atau terlepas dari kelompok budayanya, misalnya, "apakah saya melihat diri saya sebagai anggota dari kelompok budaya saya?"

Kedua kepentingan (importance), mengarah pada perasaan penting atau kelekatan yang dimiliki seseorang terhadap kelompok budayanya. Aspek ini mengindikasikan seberapa penting suatu budaya dan segala hal yang menyangkut tentang budaya tersebut bagi seseorang, misalnya, "apakah menjadi anggota dari kelompok budaya saya itu penting?"

Ketiga ialah keberhargaan(esteem), meliputi perasaan positif atau negatif saat menjadi anggota kelompok budaya. Aspek ini mengindikasikan apakah seseorang mendapatkan harga diri (self-esteem) yang positif atau negatif dengan melihat dirinya sebagai anggota suatu kelompok budaya, misalnya, "apakah saya suka menjadi anggota kelompok budaya saya?"

Keempat ialah mempertahankan identitas (maintenance), mengarah pada seberapa besar seseorang ingin mempertahankan identitasnya sebagai anggota suatu kelompok budaya. Aspek ini mengindikasikan apakah seseorang ingin mempertahankan dan menampilkan identitas dirinya sebagai anggota kelompok budayanya atau sebaliknya, mengubah atau menyembunyikannya, misalnya, "apakah saya ingin bertahan sebagai anggota dari kelompok budaya saya?"

Kelima ialah ekspresi perilaku (behavioral expression), yang meliputi cara seseorang mengekspresikan keyakinan dan perasaannya sebagai anggota dari suatu kelompok budaya dalam kehidupan sehari-hari. Ekspresi ini dapat berupa penggunaan bahasa, praktek agama, cara berpakaian dan makanan, dan keterlibatan dalam hubungan sosial dengan cara yang sesuai budayanya, misalnya, "apakah saya mengekspresikan identitas budaya saya?"

Menurut Jameson (2007), identitas budaya memiliki beberapa karakteristik penting. Pertama, identitas budaya dipengaruhi oleh hubungan dekat, seperti hubungan dengan anggota keluarga atau teman. Orang-orang yang memiliki teman dekat dari budaya yang berbeda, secara bertahap dan tidak sengaja akan mengadopsi beberapa kepercayaan dan sikap dari rekannya tersebut.

Kedua, identitas budaya berubah seiring dengan waktu. Dalam perjalanan kehidupan, banyak orang berpindah kelas ekonomi, bidang profesi, kebangsaan bahkan agamanya. Orang-orang memang tidak mengubah bahasa aslinya, tetapi kemudian banyak dialek baru yang lebih sering digunakan dalam kehidupannya sehari-hari. Semua perubahan tersebut mempengaruhi identitas budaya masyarakat.

Ketiga, identitas budaya erat kaitannya dengan kekuasaan dan hak istimewa. Kekuasaan dan hak istimewa seseorang menjadi terbatas ketika ia tidak memiliki kemampuan untuk mengontrol persepsi orang lain mengenai identitas budayanya. Beberapa komponen dari identitas budaya mungkin dapat disembunyikan. Sebagai contoh, bagi beberapa orang, ciri-ciri fisik dapat memperjelas latar belakang etnisnya, tetapi tidak bagi sebagian orang lainnya. Orang-orang dapat memilih apakah mereka akan membiarkan orang lain tahu mengenai latar belakang budayanya atau tidak. Komponen biologis, budaya, ras, etnis, jenis kelamin, usia, terkadang membuat orang lain merasa terpinggirkan dari hakhaknya. Di sisi komponen biologis, misalnya etnik tertentu, seperti etnis Tionghoa, tidak mungkin 
disembunyikan di situasi pergaulan Indonesia, karena secara jelas tergambar secara fisik. Namun orang Tionghoa tertentu, seperti orang-orang Tionghoa di daerah Benteng yang secara tampilan fisiknya sama seperti kebanyakan kelompok budaya yang dianggap orang sebagai pribumi, bisa saja memilih tidak mengakui identitasnya sebagai orang Tionghoa, karena kekhawatiran mendapatkan diskriminasi karena dari identitas Tionghoa-nya.

Keempat, identitas budaya bisa membangkitkan emosi. Orang mungkin saja memiliki perasaan positif, negatif, netral, atau ambigu terhadap komponen identitas budaya mereka sendiri. Bahkan terkadang, baik secara sadar ataupun tidak, seseorang dapat memiliki perasaan negatif terhadap komponen identitas mereka sendiri. Ketika seseorang bersikap negatif terhadap identitas budaya orang lain, beberapa kemungkinan bisa terjadi. Ting-Toomey (1986) berkata bahwa orang mengembangkan sikap positif atau negatif terhadap identitas budaya mereka sendiri berdasarkan pandangan orang lain terhadap identitasnya.

Kelima, identitas budaya bisa dinegosiasikan melalui komunikasi. Identitas budaya dapat dinegosiasikan melalui komunikasi tetapi hanya ketika orang tersebut sadar dengan komponen identitas budaya mereka dan merasa nyaman untuk mendiskusikannya dengan orang lain.

\section{Identitas Budaya dengan Tempat Subjek Dibesarkan}

Banyak golongan penduduk muda dari daerah-daerah luar Kota Medan yang lebih memilih bermigrasi ke Kota Medan, dengan tujuan untuk menambah ilmu atau menuntut ilmu di perguruan tinggi yang tidak tersedia di desa asalnya (Surianingsih, 2006). Arus perpindahan ini mengumpulkan berbagai macam suku bangsa dan menjadikan Medan sebagai kota yang mempunyai budaya plural. Dengan begitu, baik sebagai penduduk yang dibesarkan di suatu kota, maupun sebagai penduduk pendatang, keduanya memiliki kesempatan yang sama untuk bisa menjadi bagian dari suatu perguruan tinggi (Bruner, dalam Nainggolan, 2006).

Di perguruan tinggi sendiri, perbedaan budaya dan pendidikan multikultural sudah menjadi hal yang biasa ditemui (Banks; Birkel: Grottkau \& Nickolai-Mays; Ridley dkk., dalam Hovater, 2007; Hogg \& Vaughan, 2012). Pendidikan seperti ini didesain untuk mengubah lingkungan pendidikan supaya mahasiswa-mahasiswa dari kelompok etnis yang berbeda, gender yang berbeda, dan dari masingmasing kelompok kelas sosial akan mendapatkan kesempatan pendidikan yang sama di perguruan tinggi (Bank \& Bank, dalam Hovater, 2007; Hogg \& Vaughan, 2012).

Bagi mahasiswa pendatang (bukan lahir dan besar di Kota Medan), mereka memerlukan proses adaptasi ketika pertama kali bergabung dengan mahasiswa lainnya yang berasal dari latar belakang budaya yang berbeda dan ketika semakin berkurangnya intensitas berinteraksi dengan budaya asli yang selama ini mereka hadapi sehari-hari. Dalam proses adaptasi ini, menurut Jameson (2007), mereka akan secara bertahap mengadopsi beberapa kepercayaan dan sikap dari teman dekatnya di lingkungan baru. Ketika ia berteman dekat dengan orang yang berlatar belakang budaya yang berbeda, maka 
akan memungkinkan bagi mereka mengadopsi budaya yang berbeda tersebut, dan hal ini kemudian mempengaruhi identitas budaya mereka. Selain itu, Berry (1999) mengungkapkan bahwa pendidikan formal di kota tidak begitu mempertimbangkan kebutuhan budaya seseorang, sehingga cenderung memberi dampak negatif bagi identitas budayanya karena kurikulumnya tentu tidak berhubungan dengan kegiatan tradisional budaya seseorang. Media yang lebih banyak ditemui di kota juga berpengaruh terhadap identitas budaya seseorang. Sebagai contoh, ada media yang menampilkan stereotipe yang kurang baik tentang suatu budaya, bisa saja menimbulkan penolakan oleh orang dari budaya yang bersangkutan terhadap identitas budayanya (Berry, 1999).

Menurut Berry (1999), kehadiran keluarga merupakan faktor yang krusial yang mempengaruhi identitas budaya seseorang. Semakin sedikit intensitas kehadiran orangtua (atau orang yang memperkenalkan dan mengajarkan hal-hal berkenaan dengan budaya mereka) bagi seorang anak, maka semakin hilang kepekaan dan kesadaran akan identitas budaya (sense of cultural identity) anak (Berry, 1999). Tempat tinggal yang terletak jauh dari budayanya menyebabkan seseorang kehilangan kontak dengan budaya mereka. Sementara, seseorang yang tetap berhubungan dengan budayanya, cenderung memiliki kepekaan akan identitas budaya yang kuat pula. Dilihat dari bahasa, seseorang yang tidak memiliki pengetahuan yang banyak akan bahasa asli budayanya cenderung mengalami dampak yang negatif bagi identitas budayanya. Hubungan dengan teman juga merupakan faktor penting dalam pemeliharaan identitas budaya seseorang (Berry, 1999).

Dengan keadaan seperti ini, mahasiswa yang dibesarkan di daerah asal sebuah budaya, akan lebih kuat identitas budayanya. Sekalipun mereka bermigrasi ke kota untuk berkuliah, lamanya waktu yang mereka habiskan di daerah asal tersebut jauh lebih lama dibandingkan waktunya untuk berkuliah. Sementara bagi mahasiswa yang seumur hidupnya tinggal di kota, yang jauh dari daerah asal budayanya, sangat sedikit kesempatan yang memungkinkannya berhubungan langsung dengan budayanya.

\section{Budaya Batak Toba}

Etnik Batak Toba adalah salah satu dari lima sub etnik Batak yang merupakan penduduk Sumatera Utara yaitu Toba, Mandailing, Simalungun, Karo, dan Dairi atau Pak-pak (Harahap \& Siahaan, 1987; Baiduri, 2015). Individu yang dinyatakan Batak dalam arti geneologis, antropologis dan etnologis mempunyai ciri kebudayaan yang sama, yaitu sistem kekerabatan dan sosial Dalihan na Tolu atau Singkep Sitelu (Karo). Semua kelompok ini berbicara dengan bahasa dari suatu rumpun bahasa dan memiliki adat yang hampir sama (Singarimbun, 1975), walaupun menjalani proses sejarah dan budaya yang berbeda. Dalihan na Tolu, secara harafiah dapat diartikan sebagai “Tungku Nan Tiga”. Dalam struktur sosial orang Batak Toba yang menjadi subjek studi ini, selalu terdapat tiga unsur yang didasarkan pada garis keturunan dan sistem perkawinan. Ketiga unsur tersebut adalah dongan tubu atau dongan sabutuha yaitu saudara semarga (clan), hula-hula yaitu sumber marga istri, dan anak boru yaitu marga penerima istri. Ketiga unsur ini saling terkait dan membutuhkan, bersifat relatif dan dapat berubah- 
ubah (Simanjuntak, 2001). Setiap orang Batak Toba memiliki ketiga posisi tersebut. Ada saatnya dia menjadi hula hula, ada saatnya menempati posisi dongan tubu dan ada saatnya menjadi anak boru .

Tujuan hidup atau misi budaya orang Batak yaitu hagabeon (diberkati karena keturunan), hamoraon (kekayaan), dan hasangapon (kehormatan) dapat dipandang sebagai pedoman mereka dalam bertindak dan berperilaku dalam kehidupannya (Harahap \& Siahaan, 1987). Tujuan hidup orang Batak pada masa kini telah mengalami pergeseran makna seiring dengan perkembangan ekonomi, sosial, dan politik yaitu menjadi akses kepada modal, tenaga kerja, barang-barang non-material seperti informasi, pengetahuan, pendidikan, dan jaringan dengan kaum elite Batak Toba (Simbolon, 1998).

Dalam hubungannya dengan tujuan hidup yang pertama, yaitu hagabeon (diberkati karena keturunan), prinsip "banyak anak banyak rezeki” sebenarnya berlaku dalam kehidupan orang Batak. Namun demikian, kecenderungan tersebut telah mulai bergeser bukan lagi banyak anak yang menjadi tujuan, melainkan anak yang berkualitas (berpendidikan). Sebagaimana juga motto hidup orang Batak Toba "anakkokin do hamoraon di ahu" yang artinya anak adalah harta yang paling berharga. Implikasinya, mereka akan berusaha semaksimal mungkin menyekolahkan anaknya walaupun dalam keadaan yang terbatas. Ini menunjukkan bahwa pendidikan anak mendapat tempat dan nilai yang lebih tinggi dari nilai yang lain (Napitupulu, 2011).

Pendidikan ternyata memegang peranan penting sebagai pendorong bagi keluarga mereka dalam rangka mencapai tujuan hidup atau misi budaya: hagabeon (diberkati karena keturunan), hamaraon (kekayaan), dan hasangapan (kehormatan). Satu-satunya cara yang strategis untuk mencapai misi budaya tersebut, tidak lain, ialah melalui pendidikan. Dengan pendidikan, mereka lebih menjadi maju, berkembang dan sejahtera. Misi budaya ini didukung dengan nilai-nilai agama terutama agama Kristen, sehingga antara nilai-nilai budaya dan agama saling menyatu dan sinergis. Oleh karena itu, sejak masuknya agama Kristen mereka merasa lebih menjadi orang Batak Toba yang baik dan berpendidikan tidak lain untuk mencapai misi budaya tersebut (Baiduri, 2015).

Akan menjadi suatu ironi tentunya, jika tujuan budaya ini, dimana sekolah yang dalam hal ini Pendidikan Tinggi (yang kebanyakan berada di kota-kota besar bukan berada di daerah asal), merupakan media untuk mencapai misi budaya sebagai orang Batak Toba, di satu sisi. Namun di sisi lainnya juga merupakan salah satu faktor yang mengurangi identitas budaya sebagai orang Batak Toba. Padahal dalam proses pergaulan antar budaya, untuk proses adaptasi maupun modal awal sebagai dasar karakter untuk menghadapi tantangan ke depan, pemahaman akan nilai-nilai yang kita miliki justru dibutuhkan sekaligus pemahaman akan nilai-nilai orang lain. Tentunya motivasi untuk memahami nilai-nilai budaya sendiri akan berkurang bila identitas budaya seseorang berkurang. Nilai positif yang dimiliki oleh budaya Batak Toba ini dapat dianggap sebagai kebijaksanaan suatu budaya menghadapi tantangan perubahan atau dianggap sebagai kearifan lokal. Kebijaksanaan ini tentunya perlu dijaga agar tetap ditransmisikan dari generasi ke generasi sebagai bekal untuk mampu menghadapi tantangan ke depan. 


\section{METODE}

\section{Partisipan}

Partisipan adalah 130 mahasiswa Universitas Sumatera Utara yang bersuku Batak Toba, terdiri dari 65 mahasiswa Batak Toba yang dibesarkan di Kota Medan dan 65 mahasiswa Batak Toba yang dibesarkan di Tanah Batak Toba. Partisipan ini terdiri dari 56 laki-laki dan 74 perempuan, dengan rentang usia 16 sampai 24 tahun. Partisipan kami rekrut secara incidental. Kami memberikan insentif bagi setiap partisipan yang ikut serta.

Sampel diambil dengan menggunakan teknik accidental sampling, dengan beberapa karakteristik yang harus dipenuhi oleh subjek yaitu: 1) mahasiswa Universitas Sumatera Utara, 2) bersuku Batak Toba, dan 3) berasal dari Kota Medan dan berasal dari daerah asli Batak Toba.

\section{Desain Penelitian}

Penelitian ini merupakan penelitian komparasi non eksperimental, yang terdiri dari dua kelompok sampel penelitian. Kelompok pertama merupakan kelompok mahasiswa yang dibesarkan di Kota Medan dan kelompok ke dua adalah mahasiswa yang dibesarkan di daerah asal Budaya Batak Toba. Daerah dibesarkan ini merupakan variabel independen pada penelitian ini. Adapun variabel dependen adalah identitas budaya, yang diukur melalui skala cultural identity yang didesain melalui teori cultural identity dari Berry (1999).

\section{Prosedur}

Penelitian ini pada dasarnya melalui dua tahapan. Tahap pertama merupakan persiapan dan tahap kedua ialah pelaksanaan penelitian. Tahap persiapan, antara lain: 1) pembuatan alat ukur, pada tahap ini, peneliti membuat alat ukur berupa skala cultural identity, 2) uji coba alat ukur, berdasarkan professional judgment dan selanjutnya diuji-cobakan pada sampel yang memiliki karakteristik populasi penelitian, dan 3) dilakukan revisi berdasarkan hasil uji coba, untuk kemudian dibuatkan dalam bentuk booklet.

Pada tahap pelaksanaan, dilakukan pengambilan data lapangan. Booklet yang berisi skala cultural identity serta data demografik diberikan pada subjek penelitian sesuai kriteria penelitian.Pengumpulan data ini dilakukan di berbagai Fakultas di Universitas Sumatera Utara, dengan bantuan beberapa rekan. Tahap pengolahan data dilaksanakan setelah data telah terkumpul.

\section{Instrumen}

Untuk keperluan penelitian ini, kami membuat skala cultural identity yang berisikan item-item untuk mengukur variabel penelitian berdasarkan aspek-aspek identitas budaya yang diungkapkan dalam teori Berry (1999). 
Skala cultural identity ini terdiri dari 41 item, mencakup lima aspek, yaitu perception (9 item), importance (8 item), esteem (8 item), maintenance (9 item), dan behavioral expression ( 7 item). Gabungan kelima aspek ini membentuk satu skala cultural identity yang reliabel (contohnya, "Ketika berbicara dengan sesama orang Batak Toba, saya menggunakan bahasa Batak Toba", "Saya beruntung terlahir sebagai orang Batak Toba") dengan nilai reliabilitas $\alpha=.95$ (corrected item-total correlation $=.343$ sampai.756).

Skor semua subjek ini dapat dikategorisasikan menjadi 3 kelompok terpisah dengan kontinum jenjang mulai dari skor kuat $(x \geq 123)$, sedang $(82 \leq x<123)$ dan lemah $(x<82)$ untuk variabel identitas budaya. Pengkategorisasian ini mengacu pada dasar teoritis (data hipotetik; artinya data yang dibangun dari operasionalisasi variabel berdasarkan teori tertentu), dengan standar deviasi yang digunakan adalah perkalian satu standar deviasi (Azwar, 2005).

\section{Teknik Analisis}

Analisis data yang digunakan dalam penelitian ini adalah uji statistik $t$-test untuk melihat perbedaan di antara kelompok mahasiswa yang besar di Medan dan mahasiswa yang dibesarkan di tanah kelahiran Batak Toba. Sebelum dilakukan uji t-test, terlebih dahulu dilakukan uji asumsi penelitian yang meliputi: normalitas sebaran data, menggunakan uji one-sample Kolmogorov-Smirnov dengan bantuan SPSS version 16.0. for Windows. Data dikatakan terdistribusi normal jika nilai $\rho>.05$ dan uji homogenitas, pengukuran homogenitas dilakukan dengan Anova dengan bantuan SPSS version 16.0 for Windows.

\section{ANALISIS DAN HASIL}

Penelitian komparasi ini menggunakan uji asumsi normalitas dan homogenitas. Untuk uji asumsi normalitas, kami menggunakan Kolmogorov-Smirnov Test dengan SPSS version 16,0 for Windows. Hasil menunjukkan bahwa semua variabel memiliki data yang terdistribusi normal, hal ini ditandai dengan probabilitas atau nilai $\mathrm{p}>.05(\mathrm{p}=.607)$. Untuk uji homogenitas, kami menggunakan Levene's Test dengan SPSS version 16,0 for Windows. Hasil menunjukkan bahwa sampel yang terlibat dalam penelitian ini bersifat homogen terhadap populasi, hal ini ditandai dengan nilai signifikansi lebih besar dari $\alpha(\operatorname{sig}=0.75 ; \alpha=0.05)$.

Berdasarkan hasil penelitian, kami melakukan pengkategorisasian tingkat identitas budaya sebagai berikut: 
Tabel 1.

Kategorisasi Data Variabel Penelitian

\begin{tabular}{ccccc}
\hline Tempat Lahir & $\begin{array}{c}\text { Rentang } \\
\text { Nilai }\end{array}$ & Kategori & $\begin{array}{c}\text { Jumlah } \\
\text { Subjek }\end{array}$ & Persentase \\
\hline \multirow{2}{*}{ Tanah Batak Toba } & $\mathrm{x}<82$ & Lemah & 0 & $0 \%$ \\
& $\mathrm{x} \geq 123$ & Sedang & 18 & $27.69 \%$ \\
\hline \multirow{2}{*}{ Kota Medan } & $\mathrm{x}<82$ & Kuat & 47 & $72.31 \%$ \\
& $\mathrm{x} \leq \mathrm{x}<123$ & Sedang & 0 & $0 \%$ \\
& $\mathrm{x} \geq 123$ & Kuat & 32 & $49.23 \%$ \\
\hline
\end{tabular}

Sebelum dilakukan pengujian statistik, maka terlebih dahulu dilakukan perumusan hipotesa statistik, yaitu:

(1) $\mathrm{H}_{0}$ (hipotesa nihil): tidak ada perbedaan identitas budaya yang signifikan pada orang Batak Toba ditinjau dari tempat subjek dibesarkan.

(2) $\mathrm{H}_{\mathrm{A}}$ (hipotesa alternatif): ada perbedaan identitas budaya yang signifikan pada orang Batak Toba ditinjau dari tempat subjek dibesarkan.

Dari 65 subjek yang dibesarkan di Tanah Batak Toba didapati nilai rata-rata skor ialah 131.06 ( $\mathrm{SD}=14.802)$, sedangkan dari 65 subjek yang dibesarkan di Kota Medan didapati nilai rata-rata skor ialah $122.37(\mathrm{SD}=15.473)$. Perbandingan rata-rata tersebut menunjukkan ada perbedaan identitas budaya di antara kedua kelompok. Dari hasil penghitungan uji t, didapati hasil nilai $t=3.273(d f=128 ; p<.05$; $\rho=.001)$, sehingga dapat disimpulkan bahwa hipotesa penelitian $\left(\mathrm{H}_{\mathrm{A}}\right)$ diterima. Dengan demikian, disimpulkan bahwa ada perbedaan identitas budaya yang signifikan pada orang Batak Toba ditinjau dari tempat subjek dibesarkan.

Di samping hasil utama penelitian ini, juga diungkapkan hasil tambahan. Pertama, ditemukan adanya perbedaan identitas budaya pada orang Batak Toba berdasarkan jenis kelaminnya (pada mahasiswa Batak Toba yang besar di Tanah Batak Toba, mean laki-laki=133,82, mean perempuan = 127.9; yang dibesarkan di Kota Medan, mean laki-laki = 124,91, mean perempuan $=120,98$ ). Subjek laki-laki memiliki identitas budaya yang lebih kuat dibandingkan subjek perempuan. Hasil ini dapat dilihat di tabel berikut:

Tabel 2.

Penyebaran Subjek yang Dibesarkan di Tanah Batak Toba Berdasarkan Jenis Kelamin

\begin{tabular}{cccc}
\hline Jenis Kelamin & Jumlah & Persentase & Mean \\
\hline Laki-laki & 33 & 50.77 & 133.8182 \\
Perempuan & 32 & 49.23 & 127.1935 \\
\hline Total & 65 & 100 & \\
\hline
\end{tabular}


Tabel 3.

Penyebaran Subjek yang Dibesarkan di Kota Medan Berdasarkan Jenis Kelamin

\begin{tabular}{cccc}
\hline Jenis Kelamin & Jumlah & Persentase & Mean \\
\hline Laki-laki & 23 & 35.38 & 124.913 \\
Perempuan & 42 & 64.62 & 120.9762 \\
\hline Total & 65 & 100 & \\
\hline
\end{tabular}

Kedua, hasil penelitian menampilkan ada perbedaan identitas budaya pada orang Batak Toba berdasarkan lamanya subjek tinggal di Kota Medan (untuk mahasiswa yang dibesarkan di Medan, masa tinggal terendah 18-20 tahun, mean= 125.3; sedangkan masa tinggal 22-24 tahun, yang tertinggi, mean= 117.42; mahasiswa yang dibesarkan di Tanah Batak, masa tinggal terendah 0-2 tahun, mean=131.2; sedangkan masa tinggal tertinggi ialah 6-8 tahun, mean=126.2). Hasil ini menggambarkan bahwa identitas budaya kelompok subjek yang paling lama tinggal di Kota Medan (paling lama terpisah dari Tanah Batak Toba) memiliki identitas budaya yang paling lemah.

\section{DISKUSI}

Di dalam penelitian ini, kami menguji perbedaan identitas budaya pada orang Batak Toba ditinjau dari tempatnya dibesarkan. Hasil penelitian ini menunjukkan bahwa ada perbedaan identitas budaya yang signifikan pada orang Batak Toba yang dibesarkan di Kota Medan dengan yang dibesarkan di Tanah Batak Toba. Dari data yang didapat, orang Batak Toba yang dibesarkan di Tanah Batak Toba memiliki identitas budaya yang lebih kuat dibandingkan yang dibesarkan di Kota Medan. Secara umum hasil penelitian ini menunjukkan arah yang sama dengan penelitian dari Nainggolan (2006), yang menyatakan rendahnya identitas budaya pada orang Batak yang merantau di Jakarta. Namun bila diperhatikan hasil yang secara umum, meskipun nilai identitas budaya para mahasiswa yang dibesarkan di Batak Toba lebih tinggi, namun nilai identitas budaya mereka yang dibesarkan di Medan masih termasuk di kategori yang tinggi. Hal ini mengindikasikan adanya kekhasan Kota Medan dibandingkan di Jakarta; meskipun para mahasiswa ini dibesarkan di Medan, namun umumnya para keluarga Batak di Medan masih menjaga keterikatan mereka dengan kampung halaman. Kota Medan dengan kekhasan tidak adanya budaya dominan, justru menguatkan pengelompokan etnis-etnis yang ada di Kota Medan. Kelompok Punguan sebagai kelompok kekerabatan satu marga orang Batak tetap terjaga di Medan, sebagai daerah rantau (Baiduri, 2015). Berbeda dengan penelitian dari Nainggolan (2006), keterikatan dan keeratan kekerabatan di antara orang Batak di Jakarta cenderung rendah.

Selain hasil tersebut di atas, kami juga menemukan beberapa hasil tambahan sehubungan dengan identitas budaya. Pertama, hasil penelitian membuktikan bahwa ada perbedaan identitas budaya 
pada orang Batak Toba berdasarkan jenis kelaminnya. Subjek laki-laki memiliki identitas budaya yang lebih kuat dibandingkan subjek perempuan. Bila dilihat kembali budaya Batak Toba, memang nilai anak laki-laki dan nilai anak perempuan berbeda, yang disebut sebagai anak pada pernyataan "anakkokin do hamoraon di ahu" (atau anakku adalah hartaku yang paling berharga) adalah anak laki-laki, sehingga bisa dimengerti mahasiswa laki-laki pada sampel penelitian ini memiliki identitas budaya yang lebih tinggi dibandingkan dengan subjek perempuan. Dalam hal ini hasil penelitian dari Baiduri (2015) juga perlu dicermati. Ia melakukan studi etnografi pada kelompok keluarga inanginang pedagang di Medan. Hasil penelitiannya justru menunjukkan peran perempuan yang kuat, untuk mempertahankan keberlangsungan adat di kalangan orang Batak ini. Tentunya hasil temuan ini didapatkan di kalangan ibu-ibu, generasi yang lebih tua dari sampel penelitan ini. Harapan utama untuk tetap menjaga keberlangsungan adat dan budaya, sebagai modal dasar karakter baik orang Batak tentunya perlu dikuatkan lagi agar karakter positif ini, sebagai suatu local wisdom orang Batak, tetap terjaga kelestariannya.

Kedua, hasil penelitian menyatakan bahwa ada perbedaan identitas budaya pada orang Batak Toba berdasarkan lamanya subjek tinggal di Kota Medan. Hasil menggambarkan bahwa identitas budaya kelompok subjek yang paling lama tinggal di Kota Medan (paling lama terpisah dari Tanah Batak Toba) ialah yang paling rendah skornya. Hasil ini mendukung asumsi dan hipotesa yang ditegakkan pada penelitian ini, yakni semakin lama seseorang dibesarkan di kampung halamannya dalam hal ini mahasiswa Batak, semakin tinggi pula identitas budayanya. (Berry, 1999)

Hal yang menjadi kekurangan dalam penelitian ini adalah peneliti tidak memastikan keseluruhan subjek yang terlibat dalam penelitian ini adalah subjek yang memiliki ibu bersuku Batak Toba juga. Seorang Batak Toba dapat dipastikan memiliki ayah bersuku Batak Toba karena budaya Batak Toba mengikuti prinsip patrilineal dalam keluarganya. Jika ibu subjek berasal dari suku yang berbeda, maka dalam keluarganya sudah ada percampuran budaya yang bisa mempengaruhi identitas budayanya. Untuk pertimbangan ini, dilakukanlah komunikasi personal lanjutan dengan salah satu subjek yang dibesarkan di Tanah Batak Toba, yang ternyata memiliki ibu yang bersuku Batak Simalungun. Dari hasil komunikasi personal ini ditarik kesimpulan bahwa suku yang dimiliki ibu subjek tidak mendatangkan pengaruh yang signifikan terhadap identitas budayanya. Hal ini ditandai dengan bahasa yang keluarga mereka gunakan sehari-hari tetap bahasa Batak Toba dan adat-adat yang pernah mereka adakan tetap mengikuti aturan adat Batak Toba karena mereka tinggal di Tanah Batak Toba, yang memegang teguh adat Batak Toba. Oleh karena itu, berdasarkan wawancara ini, tempat subjek dibesarkan lebih memberi pengaruh terhadap identitas budaya subjek dibandingkan suku ibunya. Terlepas dari hasil komunikasi personal ini, tetaplah penting untuk mengontrol suku ibu, sehingga data yang didapat pun lebih akurat. 


\section{SIMPULAN DAN SARAN}

\section{Simpulan}

Pertama, terdapat perbedaan identitas budaya pada mahasiswa Batak Toba, sebagai partisipan penelitian ini berdasarkan tempat dibesarkan. Mahasiswa Batak Toba yang dibesarkan di Tanah Batak memiliki identitas budaya yang lebih tinggi dibandingkan mahasiswa Batak Toba. Kedua, secara umum kedua kelompok partisipan penelitian, baik yang dibesarkan di Tanah Batak maupun yang di Medan memiliki identitas budya yang tergolong tinggi. Ketiga, berdasarkan jenis kelamin dapat diutarakan, baik pada partisipan yang dibesarkan di Tanah Batak maupun yang dibesarkan di Medan memiliki perbedaan. Partisipan laki-laki tampak memiliki identitas budaya yang lebih tinggi dibandingkan perempuan. Keempat, berdasarkan lama tinggal di Kota Medan, baik pada partisipan yang dibesarkan di Medan maupun di Tanah Batak, hasil penelitian cenderung menampilkan semakin lama tinggal di Kota Medan, semakin rendah identitas budayanya.

\section{Saran}

Saran teoretis yang dapat diberikan terkait dengan penelitian ini ialah, agar menjadi perhatian untuk penelitian selanjutnya bahwa kontrol untuk suku ibu harus dilakukan. Meskipun usaha untuk mengatasinya dengan cara menanyakan kembali pada beberapa mahasiswa Batak Toba yang memiliki ibu bukan orang Batak Toba, namun sebaiknya untuk penelitian selanjutnya sebaiknya hal ini diperhatikan.

Sebagai implikasi praktis sehubungan dengan pelestarian budaya Batak Toba, kami ingin memberikan beberapa saran yang ditujukan ke beberapa pihak. Pertama, bagi orangtua, sebaiknya tetap memperkenalkan hal-hal berkenaan dengan budaya Batak Toba dan segala adat-istiadatnya kepada anak-anak, kalau bisa sedari kecil, sehingga sedari anak-anak pun, mereka sudah terbiasa menggunakan Bahasa Batak Toba, serta sedikit demi sedikit tahu mengenai adat-istiadat dan kebiasaan dalam Batak Toba.

Kedua, bagi para tokoh adat, sebaiknya lebih sering mensosialisasikan Budaya Batak Toba ke kalangan mahasiswa yang beretnis Batak Toba agar para mahasiswa juga kembali didekatkan dengan Budaya Batak Toba.

Ketiga, bagi mahasiswa, dimana pun menuntut ilmu, sebaiknya tidak meninggalkan hal-hal yang berkenaan dengan Budaya Batak Toba dan segala adat-istiadatnya. Sekalipun tinggal menetap sejak lahir di kota, jauh dari kampung asal sukunya, sebaiknya tetap menjaga kelestarian budayanya sehingga tetap ada sampai generasi-generasi berikutnya. Hal ini bisa dimulai dengan mulai mempelajari segala hal tentang Batak Toba, dan pada akhirnya bisa dipraktikkan. 


\section{UCAPAN TERIMA KASIH}

Terima kasih kami sampaikan kepada dekan fakultas Psikologi Prof. Irmawati, karena tanpa bantuan beliau penelitian ini tidak dapat terlaksana. Terima kasih juga terhadap rekan-rekan yang melakukan penyebaran data dan para dosen di Fakulatas Psikologi USU yang membantu proses professional judgment dalam pembuatan alat ukur penelitian. Tulisan ini berasal dari hasil penelitian yang dilakukan pada tahun 2013, dan kemudian dilakukan analisis dan pembahasan ulang dengan sumber-sumber yang lebih baru. Untuk itu terima kasih pada Ratih Baiduri yang telah memberikan bahan bacaan dan tulisannya sendiri untuk rujukan baru pada penelitian ini.

\section{REFERENSI}

Baiduri, R. (2015). Bukan sekedar untuk uang: Makna kerja perempuan pedagang Batak Toba (Inanginang) di Kota Medan. Paper dipresentasikan pada Seminar Nasional "Jaringan dan Kolaborasi untuk Mewujudkan Keadilan Gender: Memastikan Peran Maksimal Lembaga Akademik, Masyarakat Sipil dan Negara", Depok, Indonesia.

Berry, J. W. (1999). Aboriginal cultural identity. The Canadian Journal of Native Studies, 19(1), 1-36.

Harahap, B. H, \& Siahaan, H. M. (1987) Orientasi Nilai-nilai Budaya Batak: Suatu Pendekatan terhadap Perilaku Batak Toba Angkola-Mandailing. Jakarta: Sanggar Willem Iskandar.

Hogg, M. A., \& Vaughan, G.M., (2012). Social Psychology (3rd ed.). London: Prentice Hall.

Hovater, S. E. (2007). Developing cultural awareness: A grounded theory study of pre-service teachers' field experiences in Taiwan (Doctoral dissertation). Ditemu kembali dari Digital Commons Database.

Inilah Penyebab Penduduk Medan Membludak. (2011, 13 September). Waspada Online. Diunduh dari: http://waspada.co.id/index.php?option=com_content\&view=article\&id=215529: inilahpenyebab-penduduk-medan-membludak\&catid=14: medan $\&$ Itemid $=27$

Jameson, D. A. (2007). Reconceptualizing cultural identity and its role in intercultural business communication. Journal of Business Communication, 44, 3, 199-235.

Kim, U., K. Yang \& K. Hwang. (2006). Indegenous and cultural psychology: Understanding people in context. New York, NY: Springer.

Nainggolan, T. (2006). Batak Toba di Jakarta, Kontinuitas dan Perubahan Identitas. Medan: Bina Media Perintis. 
Napitupulu, V. M. (2011). Pendidikan sebagai faktor dinamisasi dan integrasi sosial dalam masyarakat Tapanuli Utara. Pemikiran tentang Batak setelah 150 tahun agama Kristen di Sumatera Utara (Bungaran Antonius Simanjuntak, ed.)(263-300). Jakarta: Yayasan Pustaka Obor Indonesia.

Pelly, U. (1994). Urbanisasi dan Adaptasi: Peranan Misi Budaya Minangkabau dan Mandailing. Jakarta: LP3ES.

Pemerintah Kota Medan. (2012). Selayang Pandang Kota Medan. Diunduh dari.http://www. pemkomedan.go.id/selayang_informasi.php

Phinney, J. (1990). Ethnic identity in adolescence and adults: A review of research. Psychological bulletin, 108, 499-514.

Purwanto. (2008). Metode Penelitian Kuantitatif untuk Psikologi dan Pendidikan. Yogyakarta: Pustaka Belajar.

Schwartz, S. J., Montgomery, M. J., \&Ervin, B. (2006). The role of identity in acculturation among immigrant people: Theoretical propositions, empirical questions, and applied recommendations. Human development, 49, 1-30.

Simanjuntak, B. A. (2001). Konflik Status dan Kekuasaan Orang Batak Toba. Yogyakarta: Jendela.

Simbolon, I. J. (1998). Peasant women and access to land customary law, state law and gender-based ideology the case of the Toba-Batak (North Sumatera). Disertasi tidak dipublikasikan. Wageningen University, Netherlands.

Surianingsih.(2006). Pola Migrasi di Provinsi Sumatera Utara dan Kaitannya dengan Hukum dan Kependudukan. Journal equality,11, 2,143-150.

Tajfel, H. (1982). Social Psychology of Intergroup Relations. Annual Review of Psychology, 33, 1-39.

Ting-Toomey, S. (1986). Conflict communication styles in black and white subjective cultures. International and Intercultural Communication Annual, 10, 75-88. 